\title{
Milk Thistle, Myrrh and Mint: Herbal Plants as Natural Medicines
}

\author{
Mohamad Hesam Shahrajabian ${ }^{1 *}$, Wenli Sun ${ }^{1}$, Qi Cheng ${ }^{1,2}$ \\ 1-Biotechnology Research Institute, Chinese Academy of Agricultural Sciences, Beijing 100081, China \\ 2-College of Life Sciences, Hebei Agricultural University, Baoding, Hebei, 071000, China; Global Alliance of HeBAU-CLS\&HeQiS for BioAl- \\ Manufacturing, Baoding, Hebei 071000, China
}

\section{A B S T R A C T}

Herbs are natural products and herbal medicine has become a popular form of healthcare. Herbal-derived remedies may increase pharmacological qualities and improve prevention and treatment of several diseases. In this study, all relevant articles in English language were collected. Keywords of milk thistle, myrrh, mint and natural products were searched in Google Scholar, Scopus, Research Gate and PubMed databases. Milk thistile is a valuable widely-consumed botanical used for its various health benefits. The plant is an annual herb, belonging to Asteraceae family, which ripe seeds contain flavonoid substances. Myrrh is a sap-like substance, which is released from cuts in the barks of trees. The plant is a member of Commiphora genus. Mentha spicata is a species of mint native to Europe and South-East Asia. Mint is a creeping rhizomatous and perennial herb. In this mini-review, key roles and pharmaceutical benefits of milk thistle, myrrh and mint are described.

Keywords: Milk thistle, Myrrh, Mint, Health benefits, Natural medicine

\section{Introduction}

Herbal medications have been reported in Egyptian papyri, traditional Indian, Chinese and Greek Ayurveda and ancient Iranian texts [1-5].Herbal medicines are types of dietary supplements, which are sold as tablets, capsules, powders, teas, extracts and fresh or dried plants [6-8]. The most important health benefits of herbal medicines include their cost effectiveness, immune system strengthen, less side effects, natural healing potency, hormone and metabolism stabilizing, and affordability, compared to conventional medicines [9-14]. Medicinal plants are potential sources for the development of novel herbal drugs [15-17]. Therefore, herbal plants can be considered as promising medicines for preventing and treating diseases [18-20]. Milk thistle is a flowering plant, which grows in Mediterranean countries and is used to prepare natural remedies. Myrrh is a reddish-brown dried sap from a thorny tree, Comminphora myrrha, which is native to Southwest Asia and Northeastern Africa. Mint belongs to the Lamiaceae family, which is a rich-source of polyphenols cultivated in areas with climates ranging from tropical to temperate. The major goal of this study was to review the most important pharmaceutical benefits of milk thistle, myrrh and mint.

\section{Methods}

Online databases of ScienceDirect, PubMed, Scopus and Google Scholar were searched using keywords of milk thistle, myrrh, mint, health benefits and natural medicine for articles published between 1970 and 2020 .

\section{Resultsand Discussion}

\section{Milk thistle (Silybummarianum)}

Milk thistle (S.marianum) is a valuable widely consumed botanical plant used for its multiple health benefits [21]. It is an annual plant belonging to the Asteraceae family, whose ripe seeds contain flavonoid substances [22]. Milk thistle has been originated from the Mediterranean region and spread to other countries in Europe, Asia, Australia and America. Milk thistle seed oil has been authorized as a novel food resource, which presents a complex unique melting profile [23]. The plant growth criteria are significantly affected by chicken manure and yeast extract. Moreover, the plant silymarin production is enhanced by chicken manure and yeast extract as well [24]. Nitrogen and potassium fertilization and plant spacing significantly affect seed yield and content of the active, antiheptotoxic flavonolignans silybin (silymarin), silidianin and silicristin of S. marianum (L.) Gaertn [25]. Milk thistle includeshigh proteins, fats, flavonolignans and linoleic and oleic acids [26]. The plant 
primary extract is termed silymarin, a complex mixture thatcontains a number of structurally linked flavonolignans, flavonoids, taxifolinand other constituents. The major flavonolignans present in most extracts includesilybin $\mathrm{A}$, silybin $\mathrm{B}$, isosilybin $\mathrm{A}$ and isosilybin B, silydianin, silychristin and isosilychristin $[27,28]$. The most important therapeutic uses of silymarinincludetheir anti-diabetes, anti-dermatitis, anticancer, anti-Alzheimer, anti-Parkinson and hepatoprot- ectiveuses [29].Silymarin derived from the milk thistle plant has been used as a natural remedy for diseases of the liver and biliary tract [30-32], which appears to be safe and well tolerated [33,34]. The seeds are promising natural drugs [35]. Milk thistle botanical supplements were reported to include a wide variety of fungal species. The most important pharmaceutical benefits of milk thistle are shown in Table 1.

Table 1.Pharmaceutical benefits of milk thistle

\begin{tabular}{|c|c|c|}
\hline Benefit & Mechanism and impact & Reference \\
\hline \multirow[t]{3}{*}{ Antioxidant activity } & a. Milk thistle syrup has high antioxidant activity. & {$[36-42]$} \\
\hline & $\begin{array}{l}\text { b. The films with milk thistle extract has shown higher } \\
\text { antioxidant activities and lower solubility. }\end{array}$ & \\
\hline & $\begin{array}{l}\text { c. The bioactive properties were positively correlated } \\
\text { with phenolics/flavonoids content. }\end{array}$ & \\
\hline \multirow[t]{2}{*}{ Anti-cancer } & $\begin{array}{l}\text { a. Silymarin and a flavonoid antioxidant isolated from } \\
\text { milk thistle have shown the cancer chemopreventive } \\
\text { and anti-carcinogenic effects. }\end{array}$ & [43-47] \\
\hline & $\begin{array}{l}\text { b. Silymarin has anti-cancer activity in human breast } \\
\text { cancer, skin cancer, colon cancer, cervical cancer, } \\
\text { prostate cancer, ovarian cancer, bladder cancer and } \\
\text { lung cancer cells. }\end{array}$ & \\
\hline Liver protective effects & $\begin{array}{l}\text { a. Milk thistle appears to be relatively safe, with long- } \\
\text { term use for its potentially protective effects on the } \\
\text { liver. }\end{array}$ & [48-50] \\
\hline Anti-diabetic activity & $\begin{array}{l}\text { a. The potent hypoglycaemic and antihyperglycaemic } \\
\text { activities of an aqueous extract of milk thistle have also } \\
\text { been demonstrated animal models of diabetes. }\end{array}$ & {$[51]$} \\
\hline Anti-melanogenesis & $\begin{array}{l}\text { a. Milk thistle has a potent potential to tyrosinase } \\
\text { inhibition. }\end{array}$ & {$[52]$} \\
\hline Anti-carncerogenic & $\begin{array}{l}\text { a. The silymarin compounds are anticancerogenic } \\
\text { substances. }\end{array}$ & {$[53]$} \\
\hline Hepatoprotective effects & $\begin{array}{l}\text { a. Silibin, a flavinoligand derived from milk thistle, is a } \\
\text { dietary supplement reported to exert hepatoprotective. }\end{array}$ & {$[54-56]$} \\
\hline Antiviral effects & a. Silymarinflavonolignans had antiviral effects. & {$[57-60]$} \\
\hline Anti-inflammatory effects & $\begin{array}{l}\text { a. Anti-inflammatory effects of silymarin are related to } \\
\text { inhibition of the transcription factor nuclear factor- } \mathrm{B} B \\
\text { (NF- } \mathrm{B} \text { ), which regulates and coordinates the } \\
\text { expression of various genes involved in inflammation, } \\
\text { cell survival, differentiation and growth. }\end{array}$ & \\
\hline Anti-aflatoxin activity & $\begin{array}{l}\text { a. It has beneficial properties of milk thistle on poultry } \\
\text { growth performance in experimentally induced } \\
\text { aflatoxicosis. }\end{array}$ & {$[61]$} \\
\hline
\end{tabular}




\section{Myrrh (Commiphora spp.)}

The Genus includes nearly 190 species and is distributed in Southern Arabia (Yemen and Oman), Northeastern Africa (Somalia, Ethiopia and Sudan) and Subcontinent (India and Pakistan) [62,63]. Myrrh is a natural gum or resin extracted from a number of small, thorny tree species of the Commiphora genus. It is an herbal product, which has been used since ancient ages for traditional medications and other purposes [64,65]. The most important species of myrrh are C.africana, C.angolensis, C.boranensis, C. caudate, C.erythrae, C.gileadensis, C.glandulosa, C.guidottii, C.guillaminii, C.habessinica, C.harveyi, C.holtziana, C.humbertii, C.kataf, C.madagascariensis, C.mossambicensis, C.myrrha, C.schimperi, C.simplicifolia, C.sphaerocarpa, C.stocksiana and C.wightii. Since ancient eras, the plant has been used as a medicine and wound dressing, closely linked to the health and purification of rituals of women. Furthermore, the herbal was first described in Chinese medical literatures. The first use of myrrh was recorded in China during Tang Dynasty [66]. Traditional uses of $C$. molmol for the treatment of pain, inflammation and hyperlipidemia have been recorded [67]. Traditional use of $C$. molmol as a poultice for the treatment of cutaneous fungal infections has also been suggested [68]. Myrrh is an effective anti-microbial agent, which is reported as an excellent external remedy for mouth, throat and skin infections as well as glandular fever and brucellosis [69]. Myrrh essential oil is a promising antibacterial and cytotoxic agent[70]. Myrrh extract can be used alone or in combination with sublethaldoses of certain insecticides to control cotton leaf worms [71]. It shows antimicrobial properties on wool and silk fabrics [72]. Furthermore, myrrh essential oil includes potentials to qualify as an alternative of synthetic fungicides, particularly managing post-harvest fungal infections [73]. The oil of C.kua has shown moderate antifungal activities against Cladosporium cucumerinum[74]. Antibacterial and antiinflammatory activities of myrrh are suggested based on the results from several studies. Moreover, antiinflammatory activity of dual combination of myrrh and chamomile is reported ${ }^{75}$. Myrrh provides novel indications for itch treatment, which cannot be treated with histamine receptor blockers alone ${ }^{76}$. Hard gelatin capsules of myrrh extract are effective as pharmaceutical dosages against schistosomiasis $^{77}$. Myrrh helps maintain increased levels of white blood cells (WBC) through the healing period ${ }^{78}$. The native myrrh use for severe vulvar edema in ovarian hyperstimulation syndrome may result in substantial improvement [79].

\section{Mint (Menthaspicata L.)}

Mint (Mentha spp.) includes diverse uses, including pharmaceutical, perfumery, food and confectionery uses [80,81]. The M.spicata is a species of mint native to Europe and South-East Asia [82]. The major essential oil of M.spicata L. includes piperitenone oxide, carvone, limonene, 1,8-cineole, menthone and isomenthone [83,84]. Kofidis et al. [85] reported that the essential oil from the leaves of M.spicata included high contents of linalool. The M.spicata can improve lipid profile of blood, meat quality and microbial population in small intestine [86]. The herbal oil can decrease pains in osteoarthritis patients [87]. The most significant pharmaceutical benefits of mint are presented in Table 2.

Table 2.Pharmaceutical benefits of mint

\begin{tabular}{ll}
\hline Benefit & Mechanism and impact \\
\hline Antimicrobial activity & a. M. spicata essential oil can be considered as a natural source of bioactive phytopchemicals \\
bearing antimocribal activities. \\
b. The recovered and decanted essential oils of Mentha species demonstrated low to moderate \\
antimicrobial activity against five bacterial strains. \\
c. The oil showed great potential for its antimicrobial activities against Escherichia coli, Candida \\
albicans, Candida tropicalis and moderate activities against Staphylococcus aureus.
\end{tabular}

Anti-bacterial

Antibiotics

Anti-fungal activity

Anti-inflammatory

Antioxidant activity

Anticarcinogenic properties

a. M. spicata essential oil has antibacterial activities.

a. High total antioxidant activity in M. Spicata (79-85\%) has proved the possible use of Mentha oils as alternative antibiotics.

a. The extract of mentha spicata L. completely inhibited the mycelia growth of the pathogen.

a. Two monoterpenoid glycosides, spicatoside A and spicatoside B isolated from the whole plant has shown anti-inflammatory and hemostatic activity.

a. S-Carvone isolated from Menthaspicata possess high antioxidant activity compared to $\alpha$ tocopherol.

The aqueous fraction of $M$. spicata mediates their antigenotoxic effects by modulation of lipid peroxidation (LPO) and antioxidant enzymes. 


\section{Conclusions}

The most health benefits of milk thistle support liver health, promote skin health, decrease cholesterol, support weight loss, decrease insulin resistance, improve allergic asthma symptoms, limit spread of cancers and support bone health. The most significant benefits of myrrh oil include killing harmful bacteria, supporting oral and skin health and healing sores. The plant includes powerful antioxidant characteristics, which fight oxidative damages and kill parasites. Moreover, the herb may help kill or slow the growth of cancer cells. Myrrh compounds may help treat intestinal spasms linked to irritable bowel syndrome (IBS) as well as killing molds. The most important health benefits of mint include its goodness for digestive upsets, high antioxidant contents, memory improvement, popularity in toothpaste flavoring, breath mints and chewing gums, blood sugar decrease properties, stress reduction power, relaxation promotion and joint pain relieve due to arthritis. In conclusion, traditional medicine herbs play important roles in sustainable agriculture and food systems. They also offer significant approaches to prevent diseases.

\section{Acknowledgement}

Not applicable.

\section{Authors' Contribution}

All authors contributed equally to searching literatures and writing the manuscript.

\section{Funding/Support}

This study was supported by the National Key R\&D Program of China (research grant: 2019YFA0904700)

\section{Availability of data and materials}

Not applicable.

\section{Ethics approval and consent to participate}

Not applicable.

\section{Consent for publication}

The authors consent for the publication of this review.

\section{Financial disclosure}

The authors declare no competing interests.

\section{References}

1. Ogbaji PO, Li J, Xue X,Shahrajabian MH, Egrinya EA. Impact of Bio-fertilizer or nutrient solution on Spinach (Spinaceaeoleraeae) growth and yield in some province soils of P.R. China. CercetariAgronomice in Moldova. 2018; 51(2): 43-52.

2. Soleymani A, Shahrajabian MH. Changes in germination and seedling growth of different cultivars of cumin to drought stress. CercetariAgronomice in Moldova. 2018; 51(1): 91100.
3. Sun W, Shahrajabian MH, Cheng Q. Anise (Pimpinellaanisum 1.), a dominant spice and traditional medicinal herb for both food and medicinal purposes. Cogent Biol. 2019; 5(1673688): 1-25.

4. Sun W, Shahrajabian MH, Cheng Q. Therapeutic roles of goji berry and ginseng in traditional Chinese. J Nutr Food Secur. 2019; 4(4): 293-305.

5. Sun W, ShahrajabianMH, Cheng Q. The insight and survey on medicinal properties and nutritive components of shallot. J Med Plant Res. 2019; 13(18): 452-457.

6. Sun W, Shahrajabian MH, Cheng Q. Pyrethrum and organic and natural pesticide. J Biol Environ Sci. 2020; 14(40): 4144.

7. Sun W, Shahrajabian MH, Khoshkharam M, Shen H, Cheng Q.Cultivation of cotton in China and Iran with considering biological activities and its health benefits. CercetariAgronomice in Moldova. 2020; 1(181): 105-120.

8. Sun W, Shahrajabian MH, Khoshkharam M, Cheng Q. Adaptation of acupuncture and traditional Chinese herbal medicines models because of climate change. J Stress PhysiolBiochem. 2020; 16(1): 85-90.

9. Shahrajabian $\mathrm{MH}$, Sun W, Cheng Q. Clinical aspects and health benefits of ginger (Zingiberofficinale) in both traditional Chinese medicine and modern industry.ActaAgricScand, Sec B- Soil Plant Sci. 2019. DOI: 10.1080/09064710.2019.1606930

10. Shahrajabian MH, Sun W, Cheng Q. A review of ginseng species in different regions as a multipurpose herb in traditional Chinese medicine, modern herbology and pharmacological science. J Med Plant Res. 2019; 13(10): 213-226.

11. Shahrajabian MH, Sun W, Cheng Q. DNA methylation as the most important content of epigenetics in traditional Chinese herbal medicine. J Med Plant Res.2019; 13(16): 357-369.

12. Shahrajabian MH, Sun W, Cheng Q. A review of astragalus species as foodstuffs, dietary supplements, a traditional Chinese medicine and a part of modern pharmaceutical science. ApplEcol Environ Res. 2019; 17(6): 13371-13382.

13. Shahrajabian MH, Sun W, Zandi P, Cheng Q. A review of chrysanthemum, the eastern queen in traditional Chinese medicine with healing power in modern pharmaceutical sciences. ApplEcolEnviron Res. 2019; 17(6): 13355-13369.

14. Shahrajabian MH, Sun W, Cheng Q. Tremendous health benefits and clinical aspects of Smilax china. African J Pharm Pharmacol. 2019; 13(16): 253-258.

15. Shahrajabian MH, Sun W, Cheng Q. Traditional herbal medicine for the prevention and treatment of cold and flu in the Autumn of 2020, overlapped with COVID-19.Nat Prod Commun. 2020; 15(8): 1-10.

16. Shahrajabian MH, Sun W, Cheng Q. Product of natural evolution (SARS, MERS, and SARS-CoV-2); deadly diseases, from SARS to SARS-CoV-2. Human Vaccine Immunother. 2020. DOI: 10.1080/21645515.2020.1797369

17. Shahrajabian MH, Sun W, Cheng Q. Chinese onion and shallot, originated in Asia, medicinal plants for healthy daily recipes. NotSci Biol. 2020; 12(2): 197-207.

18. Shahrajabian MH, Sun W, Cheng Q. Considering white gold, cotton for its fiber, seed oil, traditional and modern health benefits. J Biol Environ Sci. 2020; 14(40): 25-39. 
19. Shahrajabian MH, Sun W, Shen H, Cheng Q. Chinese herbal medicine for SARS and SARS-CoV-2 treatment and prevention, encouraging using herbal medicine for COVID19 outbreak. ActaAgricScand, Sec B- Soil Plant Sci. 2020. DOI: $10.1080 / 09064710.2020 .1763448$

20. Shahrajabian MH, Sun W, Cheng Q. Chinese star anise (Illiciumverum) and pyrethrum (Chrysanthemum cinerariifolium) as natural alternatives for organic farming and health care- A review. Aust J Crop Sci. 2020; 14(03): 517-523.

21. Hammami H, Saadatian B, Hosseini SAH. Geographical variation in seed germination and biochemical response of milk thistle (Silybummarianum) ecotypes exposed to osmotic and salinity stresses. Industrial Crops and Products 2020; 152: 112507.

22. Ghavami N, Ramin AA. Salinity and temperature effects on seed germination of milk thistle. Commun Soil Sci Plant Anal. 2007; 38(19-20): 2681-2691.

23. Zhang Z-S, Wang S, LiuH, Li B-Z, Che L. Constituents and thermal properties of milk thistle seed oils extracted with three methods. LWT. 2020; 126: 109282.

24. Saad-Allah K, Fetouh MI, Elhaak MA. Induction of milk thistle (Silybummarianum L. Gaertn) growth and phytochemicals production by natural stimulants. J Appl Res Med Aroma. 2017; 6: 101-110.

25. Omer EA, Refaat AM, Ahmed SS, Kamel A,Hammouda FM. Effect of spacing and fertilization on the yield and active constituents of milk thistle, Silybummarianum. J Herbs Spices Med Plants. 1993; 1(4): 17-23.

26. Grela ER, Swiatkiewicz M, Florek M,Wojtaszewska I. Impact of milk thistle (Silybummarianum L.) seeds in fattener diets on pig performance and carcass traits and fatty acid profile and cholesterol of meat, backfat, and liver. Livest Sci. 2020; 239: 104180.

27. Albassam AA, Frye RF, Markowitz JS. The effect of milk thistle (Silybummarianum) and its main flavonolignans on CYP2C8 enzyme activity in human liver microsomes. ChemBiol Interact. 2017; 271: 24-29.

28. Lee JI, Hsu BH, Wu D, Barrett JS. Separation and characterization of silybin, isosilybin, silydianin and silychristin in milk thistle extract by liquid chromatographyelectrospray tandem mass spectrometry. J Chromatogr A. 2006; 1116(1-2): 57-68.

29. Soleimani V, Delghandi PS, MoallemSA, Karimi G. Safety and toxicity of silymarin, the major constituents of milk thistle extract: An updated review. Phytother Res. 2019; 112 .

30. Flora MDK, Hahn MDM, Rosen MDH, Benner MDK. Milk thistle (Silybummarianum) for the therapy of liver disease. Am J Gastroenterol. 1998; 93(2): 139-143.

31. Jedlinszki N, Kalomista I, Galbacs G, Csupor D.Silybummarianum (milk thistle) products in Wilson 's disease: a treatment of a threat? J Herb Med. 2016; 6(3): 157-159.

32. Karkanis A, Bilalis D, Efthimiadou A. Cultivation of milk thistle (Silybummarianum L. Gaertn), a medicinal weed. Ind Crops Prod. 2011; 34(1): 825-830.

33. Jacobs BP, Dennehy C, Ramirez G, Sapp J, Lawrence VA. Milk thistle for the treatment of liver disease: A systematic review and meta-analysis. Am J Med. 2002; 113(6): 506515
34. Ceribasi S, Turk G, Ozcelik M, Dogan G, Ceribasi AO, Mutlu SI, Erisir Z, Guvenc M, Gungoren G, Acisu TC, Akarsu SA, Kaya SO, Sonmez M, Yuce M, Yuce A, Ciftci M, Cambay Z, Bagci E, Azman MA, Simsek UG. Negative effect of feeding with high energy diets on testes and metabolic blood parameters of make Japanese quails, and positive role of milk thistle seed. Theriogenology. 2020; 144: 74-81.

35. Bhattacharya S. Milk thistle seeds in health. In book: Nuts and seeds in health and disease prevention.2020; 429-438.

36. Zheng X, Wang X, Lan Y, Shi J, Xue SJ, Liu C. Application of response surface methodology to optimize microwaveassisted extraction of silymarin from milk thistle seeds. Sep Purif Technol. 2009; 70(1): 34-40.

37. Vaknin Y, Hadas R, Schafferman D, Murkhovsky L, Bashan N. The potential of milk thistle (Silybummarianum L.), an Israeli native, as a source of edible sprouts rich in antioxidants. Int J Food SciNutr. 2008; 59(4): 339-346.

38. Pereira C, Calhelha RC, Barros L, Ferreira ICFR. Antioxidant properties, anti-hepatocellular carcinoma activity and hepatotoxicity of artichoke, milk thistle and borututu. Ind Crops Prod. 2013; 49: 61-65.

39. Pereira C, Calhelha RC, Barros L, Queiroz MJRP, Ferreira ICFR. Synergisms in antioxidant and anti-hepatocellular carcinoma activities of artichoke, milk thistle and borututu syrups. Ind Crops Prod. 2014;52: 709-713.

40. Ghelejlu SB, Esmaiili M, Almasi H. Characterization of chitosan-nanoclaybionanocomposite active films containing milk thistle extract. Int J BiolMacromol. 2016; 86: 613-621.

41. Attia YA, Hamed RS, Bovera F, El-Hamid AEHEA, AlHarthi MA, Shahba HA. Semen quality, antioxidant status and reproductive performance of rabbits bucks fed milk thistle seeds and rosemary leaves. AnimReproduct Sci. 2017; 184: 178-186.

42. Lucini L, Kane D, Pellizzoni M, Ferrari A, Trevisi E, Ruzickova G, Arslan D. Phenolic profile and in vitro antioxidant power of different milk thistle (Silybummarianum (L.) Gaertn.) cultivars. Ind Crops Prod. 2016; 83: 11-16.

43. Bhatia N, Zhao J, Wolf DM, Agrawal R. Inhibition of human carcinoma cell growth and DNA synthesis by silibinin, an active constituent of milk thistle: comparison with silymarin. Cancer Lett. 1999; 147(1-2): 77-84.

44. Singh RP, Agarwal R. Mechanisms and preclinical efficacy of silibinin in preventing skin cancer. Eur J Cancer. 2005; 41: 1969-1979.

45. Sing RP, Agarwal R. Prostate cancer chemopreventive by silibinin: bench to bedside. MolCarcinog. 2005; 45(6): 436442.

46. Lin A-S, Shibano M, Nakagawa-Goto K, Tokuda H, Itokawa $\mathrm{H}$, Morris-Natschke SL, Lee K-H. Cancer preventive agents. 7. Antitumor-promoting effects of seven active flavonolignans from milk thistle (Silybummarianum.) on Epstein-Bar virus activation. Pharm Biol. 2007; 54(10): 735738.

47. Mohaghegh F, Solhi H, Kazemifar AM.Silymarin (Milk Thistle) can revoke liver enzyme changes during chemotherapy of breast cancer with Taxanes. EurJ Integr Med. 2015; 7(6): 650-652. 
48. Abenavoli L, Bellentani S. Milk thistle to treat non-alcoholic fatty liver disease: dream or reality? Expert Rev GastroenterolHepatol. 2013; 7(8): 677-679.

49. Li ZX, Li M, Huang XS, Liang HM, Li JL, Huang XH. Study on the bacteriostatic effect of cinnamon oil on acneinducing bacteria. Guangdong Pharm Univ. 2018; 34: 719723.

50. Boerth J, Strong KM. The clinical utility of milk thistle (Silybummarianum) in cirrhosis of the liwer. J Herb Pharmacother. 2002; 2(2): 11-17.

51. Maghrani M, Zeggwagh NA, Lemhadri A, El Amraoui M, Michel JB, Eddouks M. Study of the hypoglycaemic activity of Fraxinus excelsior and Silybummarianum in an animal model of type 1 diabetes mellitus. J Ethnopharmacol. 2004;91: 309-316.

52. Kim JY, Kim JY, Jenis J, Li ZP, Ban YJ, Baiseitova A, Park KH.Tyrosinase inhibitory study of flavonolignans from the seeds of Silybummarianum (Milk thistle). Bioorg Med Chemi. 2019; 27(12): 2499-2507.

53. Celik HT, Guru M. Extraction of oil and silybin compounds from milk thistle seeds using supercritical carbon dioxide. $\mathbf{J}$ Supercrit Fluids. 2015;100: 105-109.

54. Jancova P, SillerM, Anzenbacherova E, Kren V, Anzenbacher P, Simanek V. Evidence for differences in regioselective and steroselectiveglucuronidation of silybindiastereomers from milk thistule (Silybummarianum) by human UDP-glucuronosyltransderases. Xenobiotica. 2011; 41(9): 743-751.

55. Brandon-Warner E, Eheim AL, Foureau DM, Walling TL, Schrum LW, McKillop IH.Silibinin (Milk Thistle) potentiates ethanol-dependent hepatocellular carcinoma progression in male mice. Cancer Lett. 2012; 326(1): 88-95.

56. El-Gazayerly ON, Makhlouf AIA, Soelm AMA, Mohmoud MA. Antioxidant and hepatoproective effects of silymarinphytosomes compared to milk thistle extract in $\mathrm{CCl}_{4}$ induced hepatotoxicity in rats. J Microencapsul. 2014; 31(1): 23-30.

57. AlthagafyHS, Graf TN, Sy-Cordero AA, Gufford BT, Paine MF, Wagoner J, Polyak SJ, Croatt MP, Oberlies NH.Semisynthesis, cytotoxicity, antiviral activity, and drug interaction liability of 7-O-methylated analogues of flavonolignans from milk thistle. Bioorg Med Chemi. 2013; 21(13): 3919-3926.

58. Bhattacharya S. Milk thistle (Silybummarianum L. Gaert.) seeds in health. In book: Nuts and Seeds in Health and Disease Prevention. 2011; 759-766.

59. Fanoudi S, Alavi MS, Karimi G, Hosseinzadeh H. Milk thistle (SilybumMarianum) as an antidote or a protective agent against natural or chemical toxicities: a review. Drug ChemToxicol. 2020; 43(3): 240-254.

60. Ramasany K, Agrarwal R.Mutitargeted therapy of cancer by silymarin. Cancer Lett. 2008; 269(2): 352-362.

61. Alhidary IA, Rehman Z, Khan RU, Tahir M. Anti-aflatoxin activities of milk thistle (Silybummarianum) in broiler. Worlds PoultSci J. 2017; 73(3): 559-566.

62. Shen T, Li GH, Wang X-N, Lou H-X. The genus Commiphora: a review of its traditional uses, phytochemistry and pharmacology. J Ethnopharmacol. 2012; 142: 319-330.

63. Weeks A, Simpson BB. Molecular phylogenetic analysis of Commiphora (Burseraceae) yields insight on the evolution and historical biogeography of an impossible genus. MolPhylogenetEvol. 2007; 42: 62-79.

64. Alqahtani AS, Noman OM, RehmanMdT, Siddiqui NA, Alajmi MF, Nasr FA, Shahat AA, Alam P. The influence of variations of furanosesquiterpenoids content of commercial samples of myrrh on their biological properties. Saudi Pharm J. 2019;27: 981-989.

65. Abdul-Hamid M, Gallaly SR. Ameliorative effect of Pimpinellaanisum oil on immunohistochemical and ultrastructural changes of cerebellum of albino rats induced by aspartame. UltrastructPathol. 2014; 38(3): 224-236.

66. Hanus LO, Rezanka T, Dembitsky VM, Moussaieff A Myrrh- Commiphora chemistry. Biomed Papers. 2005; 149(1): 3-28.

67. Shalaby MA, Hammouda AA-E. Analgesic, antiinflammatory and anti-hyperlipidemic activities of Commiphoramolmol extract (Myrrh). J IntercultEthnopharmacol. 2014; 3(2): 56-62.

68. Mahboubi M, Kashani LMT. The anti-dermatophyte activity of Commiphoramolmol. Pharma Biol. 2016; 54(4): 720-725.

69. Abdel-Hay MH, Saleh A, El Ashry ESH, Rashed N, Salama O. Colorimetric determination of crude powdered myrrh, purifided myrrh extract, oily fraction, and its different pharmaceutical dosage forms. Spectrosc Lett. 2002; 35(2): 183-197.

70. Khalil N, Fikry S, Salama O. Bactericidal activity of myrrh extracts and two dosage forms against standard bacterial strains and multidrug-resistant clinical isolates with GC/MS profiling. AMB Express. 2020;10(21): 1-10.

71. Shonouda ML, Farrag RM, Salama OM. Efficacy of the botanical extract (myrrh), chemical insecticides and their combinations on the cotton leafworm, Spodopteralittoralisboisd (Lepidoptera: Noctuidae). J Environ Sci Health, Part B. 2000; 35(3): 347-356.

72. Salem AA, Al moudi HA. Application of myrrh extract as an eco-friendly dye and antimicrobial agent on wool and silk fabrics part 2: antimicrobial activity and fastness property. J Nat Fibers. 2020;17(4): 491-504.

73. Perveen K, Bokhari N, Siddique I, Al-Rashid SA. Antifungal activity of essential oil of Commiphoramolmol Oleo gum resin. Journal of Essential Oil Bearing Plants 3(21): 667-673.

74. Ali NAA, Wurster M, Arnold N, Lindequist U, Wessjohan L (20080 Essential oil composition from Oleogum resin of soqotraenCommiphorakua. Rec Nat Prod. 2018; 2(3): 70-75.

75. Vissiennon C, Hammoud D, Goos K-H, Nieber K, Arnhold J. Synergistic interactions of chamomile flower, myrrh and coffee charcoal in inhibiting pro-inflammatory chemokine release from activated human macrophages. Synergy. 2017; 4: 13-18.

76. Shin W-Y, Shim D-W, Kim M-K, Sun X, Koppula S, Yu SH, Kim H-B, Kim TJ, Kang T-B, Lee K-H. Protective effects of Cinnamomum cassia (Lamaceae) against gout and septic responses via attenuation of inflammasome activation in experimental models. J Ethnopharmacol. 2017; 205: 173177.

77. Hashem FM, Massoud AMA, Melokheya AM, Emad H, ElFattah Badr KA, Dawoud M. Formulation and clinical efficacy of myrrh extract in hard gelatin capsules. JBiol Active Prod Nat. 2013; 3(1): 72-86. 
78. Haffor A-SA. Effect of myrrh (Commiphoramolmol) on leukocyte levels before and during healing from gastric ulcer or skin injury. J Immunotoxicol. 2010; 7(1): 68-75.

79. Hijazi A, Al-Jaroudi D. Myrrh for treatment of severe vulvar edema in ovarian hyperstimulation syndrome. Case Rep Women's Health. 2017; 15: 8-10.

80. Zeinali H,Razmjo K, Arzani A. Diversity among Iranian mints in relation to yield and mineral content. CommunSoil Sci Plant Anal. 2003; 34(15-16): 2203-2217.

81. Prasad A, Singh AK, Chand S, Chanotiya CS, Patra DD. Effect of chromium and lead on yield, chemical composition of essential oil, and accumulation of heavy metals of mint species. CommunSoil Sci Plant Anal. 2010; 41(18): 21702186.

82. Samantaray A, Sial P, Kar M. Micro-propagation and biochemical analysis of Spear Mint (Menthaspicata). Indian J Innovations Dev. 2010; 1(7): 489-493.

83. YounisYMH, Beshir SM.Carvone-rich essential oils from Menthalongifolia (L.) Huds. ssp. schimperiBriq. And Menthaspicata L. grown in Sudan. J Essent Oil Res. 2004; 16(6): 539-541.

84. Chauhan RS,Nautiyal MC, Tava A. Essential oil composition from aerial parts of Menthaspicata L. J Essent Oil-Bear Plants. 2010; 13(3): 353-356.

85. Kofidis G, Bosabalidis A, Kokkini S. Seasonal variation of essential oils in a linalool-rich chemotype of Menthaspicara grown wild in Greece. J of Essent Oil Res. 2004; 16(5): 469472

86. Ghazaghi M, Mehri M, Bagherzadeh-Kasmani F. Effects of dietary Menthaspicata on performance, blood metabolites, meat quality and microbial ecosystem of small intestine in growing Japanese quail. Anim Feed Sci Technol. 2014; 194: 89-98.

87. Mahboubi M.Menthaspicata as natural analgesia for treatment of pain in osteoarthritis patients. Complement TherClinPract. 2017; 26: 1-4

88. Hussain AI, Anwar F, Shahid M, Ashraf M, Przybylski R. Chemical composition, and antioxidant and antimicrobial activities of essential oil of spearmint (Menthaspicata L.) from Pakistan. JEssent Oil Res. 2010;22(1): 78-84.

89. Sharafi SM, Rasooli I, Owlia P, Nadoushan MJ, Ghazanfari T, Taghizadeh M. Phytochemical bioactivides from Menthaspicata essential oil for health promotion. J Essent Oil-Bear Plants. 2010; 13(2): 237-249.

90. Sarer E, Toprak SY, Otlu B, Durmaz R. Composition and antimicrobial activity of the essential oil from Menthaspicata L. subsp. Spicata. J Essent Oil Res. 2011; 23(1): 105-108.

91. Verma RS, Pandey V, Padalia RC, Saikia D, Krishna B. Chemical composition and antimicrobial potential of aqueous distillate volatiles of Indian peppermint (Menthapiperita) and spearmint (Menthaspicata). J of Herbs Spices Med Plants. 2010; 17(3): 258-267.

92. Chrysargyris A, Xylia P, Botsaris G, Tzortzakis N. Antioxidant and antibacterial activities, mineral and essential oil composition of spearmint (Menthaspicata L.) affected by the potassium levels. Ind Crops Prod. 2017; 103: 202-212.

93. Scherer R, Lemos MF, Lemos MF, Martinelli GC, Martins JDL, Silva AGD. Antioxidant and antibacterial activities and composition of Brazilian spearmint (Menthaspicata L.). Ind Crops Prod. 2013; 50: 408-413.

94. Shahbazi Y, Shavisi N. Interactions of Ziziphoraclinopodioides and Menthaspicata essential oils with chitosan and ciprofloxacin against common food-related pathogens. LWT-Food Sci Technol. 2016; 71: 364-369.

95. Elansary HO, Ashmawy NA. Essential oils of mint between benefits and hazards. J Essent Oil Bear Plants. 2013; 16(4): 429-438.

96. Singh J, Dubeyd AK, Tripathi NN. Antifungal activity of Menthaspicata. Int J Pharmacog. 1994; 32(4): 314-319.

97. Bayan Y, Kusek M. Chemical composition and antifungal and antibacterial activity of Menthaspicata L. volatile oil. Ciencia e InvestigacionAgararia. 2018;45(1): 64-69.

98. Zheng J, Wu L-J, Zheng L, Wu B, Song A-H. Two new monoterpenoid glycosides from Menthaspicata L. Journal of Asian Natural Products Research. 2003; 5(1): 69-73.

99. Arumugam P, Priya NG, Subathra M, Ramesh A. Antiinflammatory activity of four solvent fractions of ethanol extract of Menthaspicata L. investigated on acute and chronic. EnvironToxicolPharmacol. 2008; 26(1): 92-95.

100. Arumugam P, Ramesh A.Antigenotoxic and antioxidant potential of aqueous fraction of ethanol extract of Menthaspicata (L.) against 4-nitroquinoline-1-oxide-induced chromosome damage in mice. DrugChemToxicol. 2009; 32(4): 411-416.

101. Arumugam P, Ramamurthy P, Ramesh A. Antioxidant and cytotoxic activities of lipophilic and hydrophilic fractions of MenthaSpicata L. (Lamiaceae). Int J Food Prop. 2010; 13(1): 23-31.

102. Elmastas M, Dermirtas I, IsildakO, Aboul-Enein HY. Antioxidant activity of S-carvone isolated from spearmint (MenthaSpicata L. FamLamiaceae). J LiqChromatogrRelta Technol. 2006; 29(10): 1465-1475.

103. Wang D, Chen X, Wang Q, MengY, Wang D, Wang X. Influence of the essential oil of Menthaspicata cv. Henanshixiang on sunflower oil during the deep-frying of Chinese Maye. LWT. 2011;122: 109020.

104. Mandana B, Russly AR, Ali G, Farah ST. Antioxidant activity of spearmint (Menthaspicata L.) leaves extracts by supercritical carbon dioxide $\left(\mathrm{SC}-\mathrm{CO}_{2}\right)$ extraction. IntFood Res J. 2011; 18: 543-547.

105. Chrysargyris A, Petropoulos SA, Fernandes A, Barros L, Tzortzakis N, Ferreira ICFR. Effect of phosphorus application rate on Menthaspicata L. grown in deep flow technique (DFT). Food Chem. 2019;276: 84-92.

106. Nakamura Y, Hasegawa Y, Shirota K, Suetome N, Nakamura T, Chomnawang MT, Thirapanmethee K, Khuntayaporn P, Boonyaritthongchai P, Wongs-Aree C, Okamoto S, ShigetaT, Matsu T, Park EY, Sato K. Differentiation-inducing effects of piperitenone oxide, a fragrant ingredient of spearmint (Menthaspicata), but not carvone and menthol, against human colon cancer cells. J Funct Foods. 2014; 8: 62-67.

107. Kedia A, Prakash B, Mishra PK, Chanotiya CS, Dubey NK. Antifungal, antiaflatoxigenic, and insecticidal efficacy of spearmint (Menthaspicata L.) essential oil. IntBiodeterBiodegr. 2014; 89: 29-36. 